\title{
Correlation and path coefficient analysis in Giant Taro (Alocasia macrorrhiza L.)
}

\author{
K. K. Paul ${ }^{1 *}$, M. A. Bari ${ }^{1}$ and S. C. Debnath ${ }^{1}$ \\ ${ }^{1}$ Institute of Biological Sciences, Rajshahi University, Rajshahi - 6205, Bangladesh.
}

\begin{abstract}
Genotypic and phenotypic character associations as well as direct and indirect effects were estimated for eleven characters such as plant height, petiole length, petiole breadth, leaf area index, inflorescence length, spathe length, spathe breadth, corm length, corm breadth, corm weight and yield per plant, in giant taro (Alocasia macrorrhiza L). The results revealed that plant height, LAI, corm length, corm breadth, had positive correlation with yield per plant both at genotypic and phenotypic level. Relatively higher positive and direct effect was found through petiole length, LAI and corm length and yield per plant in genotypic level. The residual effect 0.4762 represent in genotypic level about $53 \%$ of the variability observed for yield per plant was represented by these traits. In the phenotypic level highest and positive direct effect was observed with petiole length and yield per plant. Positive direct effect was also found on yield per plant by plant height, petiole length, inflorescence length, inflorescence number, spathe length and spathe breadth, corm length, corm breadth. The residual effect 0.4235 means that characters included in the present study explained about $58 \%$ variability in yield per plant at phenotypic level.
\end{abstract}

Keywords: Alocasia macrorrhiza; Genotypic correlation; Phenotypic correlation coefficient; Direct and indirect effects

\section{Introduction}

The underutilized crops, giant taro ( Alocasia macrorrhiza L.) locally called mankachu belongs to the family araceae (arum) is the staple food in many countries e.g. Hawaii, PNG, Fiji and important secondary food over the Africa and Asian countries (Coursey,1967; Plucknett,1970, Purseglove,1972). Giant Taro is a succulent herbaceous plant, reaching $4.5 \mathrm{~m}$ in height with a thick cylindrical stem arising from a basal corm. In Bangladesh two types of giant taro were found in local diverse areas. The cultivar giraman possessed high weight due to large corm length and corm breath, leaf sizes were gigantic, vertical, where dheki man possessed small sized corm due to short length and breadth of the corm and relatively saliently small leaf sizes. In Bangladesh, several types of Aroid genera and species occur in different locations /districts, which can be categorized into edible, poisonous, medicinal and ornamental Alocasia, originated in native in Ceylon (Srilanka) but widely distributed in the South East Asia subcontinent, Malayasia, Indonesia and Polynesia and has spread to parts of tropical America (Leon,1977). The food value of the edible portion of the raw stem tubers of giant taro has been reported as energy 293-599 k /100g; water 63-81 percent, crude protein 0.6-3.3 percent; fat 0.1-0.2 percent; Carbohydrate 17-27 percent; ash 1.1-1.3 percent, calcium 46-153mg /100g.; iron 0.5-1mg/L 100g; phosphorus 45-72 $\mathrm{mg} / 100 \mathrm{~g}$; niacin $0.4 \mathrm{mg} / 100 \mathrm{~g}$; riboflavin $0.02-0.03 \mathrm{mg}$ $/ 100 \mathrm{mg}$; thiamine $0.09-0.1 \mathrm{mg} / 100 \mathrm{~g}$; ascorbic acid trace
(Rashid and Daunicht,1979). The corms are baked, roasted and boiled and have great importance as a gift on formal occasions as well as industrial purposes. It has also medicinal properties such as useful in inflammations, leprosy, disease of the abdomen and spleen, leaf is used against tumours and stings of insects. Tuber is used in rheumatism, anasarca, jaundice and leprocy, mild laxative and diuretic, petioles are used for toothache and their juice for cough, earache and stomachache (Ghani, 1988; Ahmed, 2003). So Alocasia can play a significant role for nutrient status, medicinal and industrial values. Tuber yield is a complex character and governed by the number of component characters. For rational approach towards the improvement of yield selection has to be made for the components of the yield. Therefore the knowledge of association of component characters with yield is of great importance to plant breeders as it helps in their selection with more precision and accuracy. The degree of relationship and association of these components with yield can be measured by the correlation coefficient studies. Estimation of genetic association along with phenotypic correlation not only displays a clear picture of the extent of inherent association but also indicates how much of this phenotypic ally expressed correlation is influenced by the environment. Path coefficient analysis on the other hand determines the direct and indirect contribution of the characters on yield (Wright, 1921). Therefore correlation

\footnotetext{
*Corresponding author: E-mail: krshnnd@yahoo.com
} 
couple with path coefficient analysis will be an important tool to find the association and contribution of yield components to yield. Therefore the present investigation was undertaken to determine the nature and magnitude of relationships between yield and yield components and path coefficient analysis (direct and indirect effects) of yield and yield contributing characters in genotypic \& phenotypic level in giant taro (Alocasia macrorrhiza L).

\section{Materials and methods}

\section{Plant materials}

407 edible giant taro accessions were collected from aroid growing thirteen districts ( Rajshahi, Satkhira, Jessore, Bogra, Joypurhat, munshiganj, Joydevpur, Mymensingh, Barisal,kustia, Nagaon, Tangail, Khulna ) of Bangladesh in 2006 - 2007. Collected propagules are the mainly plantlets, suckers. Propagules are maintained and were grown in loamy soil in a single row of 4 meters length with inter row spacing of $100 \mathrm{~cm}$. Selected plantlets/setts were used for propagating materials. This investigation was conducted at the experimental farm of the Institute of Biological Sciences research field at Rajshahi University, Rajshahi during the on set of rainy season 2006-2008. The land in which the experiment was carried out was medium high. The soil was part of Level Barind agroecological zone marked by sandy loam with $\mathrm{pH}$ 6.5. The rainfall distribution in rabi season was very low or scanty $(<40 \mathrm{~cm})$. So that at least $3-4$ times flood irrigation were necessary. All recommended agricultural practices were followed for this crop.

The experiment was set up with superior genotypes in a Randomized Complete Block (RCB) design with three replications. In each experimental plot plant propagules are planted with row to row spacing was $1 \mathrm{~m}$ x $1 \mathrm{~m}$ and Plant to plant spacing was $1 \mathrm{~m}$. All recommended agricultural practices were followed for this crop production.

\section{Data recording}

Agro-morphological data were collected during optimum vegetative growth following descriptors of Taro with necessary modifications (Anonymous, 1999). The morphological characters were recorded from randomly selected five plants from each accession between 190 days after planting, while yield and other characters were recorded at harvest. Leaf parameters were made on two fully developed leaves per plant and recorded the average of three plants. Plant height (PLH): Maximum vertical distance reached by leaves, relative to ground level or plant height was measured from soil surface to tip of the flag leaf (terminal leaf) tip. It was measured by centimeter. Petiole length (PEL): The length between the base of the plant and point of insertion or junction of leaf expressed in centimeter. Petiole breadth (PEB): Average measurements were taken for three position of petiole such as petiole base, middle position and junction of leaf attachment (in cm). Leaf area Index (LAI): It was calculated as leaf length $\mathrm{x}$ leaf breadth $\mathrm{x} 0.75$ (Montgomery, 1911). Inflorescence length (IFL): It was measured as the total length of inflorescence from peduncle base to the tip of the inflorescence (in $\mathrm{cm}$ ). Spathe length (SPL): Spadix is a spike of flowers densely arranges around it, enclosed or accompanied by a highly specialized bract called spathe. It is characteristic of the Araceae family. The purple spadix is partially enclosed in a pale green spathe or leaf like hood. The length of spathe was measured vertically in centimeter form its base to the tip of it. Spathe breadth $(S P B)$ : Spathe breadth is measured horizontally in centimeter, which covered the total spadix. Corm length (CRL): The length of corm length was measured by scale or tape through vertically (in $\mathrm{cm}$ ). Corm breadth (CRB): Breadth of the rhizome was measured horizontally through the middle position of corm (in $\mathrm{cm})$. Corm weight $(C R W)$ : Yield per plant (YPP): It included the total weight of corm.

\section{Statistical Analysis}

The collected data were analyzed following the biometrical techniques of analysis based on mathematical model of Fisher and Co-workers (Fisher et al.,1932), developed by Mather (Mather, 1949) using the SPSS and excel software. Mean and Critical differences were worked out by the method of analysis of variance used for randomized block design. The analysis of variance for each character under the study was performed by F Test (Cochran and Cox, 1960). The critical differences, variances, Genotypic variance $\left(\sigma_{\mathrm{g}}^{2}\right)$, phenotypic variance $\left(\sigma_{\mathrm{p}}^{2}\right)$, Covariance and environment variance $\left(\sigma_{\mathrm{e}}^{2}\right)$. were worked out following Singh and Chaudhary (1977). For the purpose of correlation and path coefficient analysis, the analysis of both variance and covariance were made (Miller et al., 1958). Correlation coefficient was calculated from the variance and covariance components. Phenotypic, genotypic and environmental correlation coefficient for all possible combinations were computed from the components of variance and covariance following AL-Jibouri and Co-workers (AL-Jibouri et al., 1958) The path coefficient analysis was done by using Wright's $(1921,1923)$ formula was extended by Dewey and Lu (1959).

\section{Results and discussion}

In the present research work Eleven characters such as plant height, petiole length, petiole breadth, leaf area index, corm length, corm breadth, inflorescence length, inflorescence number, spathe length, spathe breadth, and yield per plant of giant taro were studied for estimation of correlation coefficient (phenotypic and genotypic) and path coefficient 
analysis (direct and indirect effects). The results obtained from this study are described under the following subheads:

\section{Correlation coefficients}

Genotypic and phenotypic correlation coefficient is presented in Table-1. In genotypic level plant height showed highly significant and positive correlation with inflorescence length (0.970), corm length $(0.584)$, corm breadth $(0.793)$ and yield per plant (0.544). Petiole length exhibited highly significant and positive correlation with inflorescence length (0.912) and yield per plant $(0.645)$. Only inflorescence length $(0.641)$ showed highly significant and positive correlation with the character petiole breadth. Leaf length showed highly significant and positive correlation with inflorescence length (0.998). Positive and highly significant correlation was found on inflorescence length with inflorescence number (0.718), spathe length (0.860), spathe breadth $(0.906)$, corm length
(0.581), corm breadth (0.835) and yield per plant $(0.545)$. Corm length showed positive and significant correlation with corm breadth (0.557) and yield per plant (0.510). Corm breadth showed directly positive and significant correlation with yield per plant (0.600).

In the phenotypic level plant height exhibited highly significant and positive correlation with petiole length (0.884), petiole breadth (0.694), leaf area index (0.590), inflorescence length(1.004),corm length(0.432) and corm breadth (0.554). Petiole length showed highly positive orrelation with petiole breadth $(0.486)$, inflorescence length $(0.481)$ and yield per plant (0.788). Petiole breadth showed significant and positive correlation with inflorescence length(0.448). Leaf area index exhibited significant and positive correlation with inflorescence number (1.180), spathe length(1.05), corm length(1.00), corm breadth(1.040) and yield per plant(1.083).

Table I. Genotypic(G) \& phenotypic(P) correlation coefficients for yield and yield contributing characters of giant taro (Alocasia macrorhiza L.)

\begin{tabular}{|c|c|c|c|c|c|c|c|c|c|c|c|c|}
\hline \multicolumn{2}{|c|}{ CHARACTERS } & PLH & PEL & PEB & LAI & IFL & IFN & SPL & SPB & CRL & CRB & $\mathbf{Y P P}$ \\
\hline PLH & $\begin{array}{c}\mathbf{G} \\
\mathbf{P}\end{array}$ & $\begin{array}{l}1 \\
1\end{array}$ & & & & & & & & & & \\
\hline PEL & $\begin{array}{l}\mathbf{G} \\
\mathbf{P}\end{array}$ & $\begin{array}{l}0.0035 \\
0.884 * *\end{array}$ & $\begin{array}{l}1 \\
1\end{array}$ & & & & & & & & & \\
\hline PEB & $\begin{array}{l}\mathbf{G} \\
\mathbf{P}\end{array}$ & $\begin{array}{l}-0.167 \\
0.694 * *\end{array}$ & $\begin{array}{l}-0.286 \\
0.486^{*}\end{array}$ & $\begin{array}{l}1 \\
1\end{array}$ & & & & & & & & \\
\hline LAI & $\begin{array}{l}\mathbf{G} \\
\mathbf{P}\end{array}$ & $\begin{array}{l}0.094 \\
0.590 * *\end{array}$ & $\begin{array}{l}0.009 \\
0.339\end{array}$ & $\begin{array}{l}0.033 \\
0.260\end{array}$ & $\begin{array}{l}1 \\
1\end{array}$ & & & & & & & \\
\hline IFL & $\begin{array}{c}\mathbf{G} \\
\mathbf{P}\end{array}$ & $\begin{array}{l}0.970^{* *} \\
1.004^{* *}\end{array}$ & $\begin{array}{l}0.912 * * \\
0.481 * *\end{array}$ & $\begin{array}{l}0.641 * * \\
0.448 *\end{array}$ & $\begin{array}{l}0.119 \\
0.132\end{array}$ & $\begin{array}{l}1 \\
1\end{array}$ & & & & & & \\
\hline IFN & $\begin{array}{c}\mathbf{G} \\
\mathbf{P}\end{array}$ & $\begin{array}{l}-0.215 \\
0.134\end{array}$ & $\begin{array}{l}-0.180 \\
0.180\end{array}$ & $\begin{array}{l}0.123 \\
0.118\end{array}$ & $\begin{array}{l}-0.031 \\
1.180^{* *}\end{array}$ & $\begin{array}{l}0.718^{* *} \\
0.132\end{array}$ & $\begin{array}{l}1 \\
1\end{array}$ & & & & & \\
\hline SPL & $\begin{array}{l}\mathbf{G} \\
\mathbf{P}\end{array}$ & $\begin{array}{l}-0.543 * \\
0.115\end{array}$ & $\begin{array}{l}-0.246 \\
0.100\end{array}$ & $\begin{array}{l}-0.135 \\
0.179\end{array}$ & $\begin{array}{l}-0.286 \\
1.05 * *\end{array}$ & $\begin{array}{l}0.860^{* *} \\
0.264\end{array}$ & $\begin{array}{l}-0.543 * \\
-0.552 * *\end{array}$ & $\begin{array}{l}1 \\
1\end{array}$ & & & & \\
\hline SPB & $\begin{array}{l}\mathbf{G} \\
\mathbf{P}\end{array}$ & $\begin{array}{l}-0.216 \\
0.049\end{array}$ & $\begin{array}{l}0.089 \\
0.071\end{array}$ & $\begin{array}{l}-0.051 \\
0.080\end{array}$ & $\begin{array}{l}-0.011 \\
0.007\end{array}$ & $\begin{array}{l}0.906^{* * *} \\
0.053\end{array}$ & $\begin{array}{l}-0.063 \\
0.920^{* *}\end{array}$ & $\begin{array}{l}0.030 \\
0.074\end{array}$ & $\begin{array}{l}1 \\
1\end{array}$ & & & \\
\hline CRL & $\underset{\mathbf{P}}{\mathbf{G}}$ & $\begin{array}{l}0.584 * \\
0.432 *\end{array}$ & $\begin{array}{l}0.251 \\
0.149\end{array}$ & $\begin{array}{l}0.100 \\
0.084\end{array}$ & $\begin{array}{l}0.213 \\
1.00^{* *}\end{array}$ & $\begin{array}{l}0.581 * \\
0.181\end{array}$ & $\begin{array}{l}0.090 \\
0.272\end{array}$ & $\begin{array}{l}-0.270 \\
0.044\end{array}$ & $\begin{array}{l}-0.115 \\
0.158\end{array}$ & $\begin{array}{l}1 \\
1\end{array}$ & & \\
\hline CRB & $\begin{array}{l}\mathbf{G} \\
\mathbf{P}\end{array}$ & $\begin{array}{l}0.793 * * \\
0.554 * *\end{array}$ & $\begin{array}{l}0.307 \\
0.221\end{array}$ & $\begin{array}{l}0.093 \\
0.103\end{array}$ & $\begin{array}{l}0.305 \\
1.040^{* *}\end{array}$ & $\begin{array}{l}0.835^{* *} \\
0.108\end{array}$ & $\begin{array}{l}0.057 \\
0.223\end{array}$ & $\begin{array}{l}-0.415 \\
0.137\end{array}$ & $\begin{array}{l}-0.168 \\
-0.131\end{array}$ & $\begin{array}{l}0.557^{*} \\
-0.101\end{array}$ & $\begin{array}{l}1 \\
1\end{array}$ & \\
\hline $\mathbf{Y P P}$ & $\underset{\mathbf{P}}{\mathbf{G}}$ & $\begin{array}{l}0.544^{*} \\
0.421\end{array}$ & $\begin{array}{l}0645 * * \\
0.788 * *\end{array}$ & $\begin{array}{l}0.360 \\
0.050\end{array}$ & $\begin{array}{l}0.293 \\
1.083^{*} *\end{array}$ & $\begin{array}{l}0.545^{*} \\
0.215\end{array}$ & $\begin{array}{l}0.121 \\
0.150\end{array}$ & $\begin{array}{l}-0.338 \\
0.052\end{array}$ & $\begin{array}{l}-0.110 \\
-0.202\end{array}$ & $\begin{array}{l}0.510^{*} \\
-0.096\end{array}$ & $\begin{array}{l}0.600 * * \\
0.448 * *\end{array}$ & $\begin{array}{l}1 \\
1\end{array}$ \\
\hline
\end{tabular}

* Significant at 0.05 level $\quad * *$ significant at 0.01 level

Plant height (PLH), Petiole length (PEL), Petiole breadth (PEB), Leaf area Index (LAI), Inflorescence length (IFL), Inflorescence number, Spathe length (SPL), Spathe breadth (SPB), Corm length (CRL), Corm breadth (CRB),Corm weight (CRW), Yield per plant (YPP). 
Inflorescence number showed significant and positive correlation with spathe breadth $(0.920)$. Corm breadth showed significant and positive correlation was found with yield per plant (0.488).

\section{Path analysis}

Path analysis was computed both phenotypic and genotypic levels to measure the direct and indirect effects of yield and yield contributing characters of giant taro presented in Table 2. Plant height showed high and positive direct effect on yield per plant (0.1706). High positive indirect effects were noticed through spathe length $(0.1291)$, corm length $(0.4855)$ and corm breadth $(0.2285)$. Direct genotypic association of petiole length on corm yield was very strong and positive (0.645). Its direct effect on yield per plant was (0.5340). Indirect effect was found through corm length (0.2086). The direct effect of leaf area index on yield per plant was positive (0.3232). Positive indirect effect was found through corm length (0.1771). Inflorescence length showed positive indirect effects through plant height $(0.1655)$, petiole length $(0.4870)$, petiole breadth $(0.1562)$, corm length $(0.4830)$ and corm breadth $(0.2406)$. Direct effect of corm length on yield per plant was positive $(0.8313)$ attitude in nature. Indirect positive effects were also observed through petiole length (0.1340) and corm breadth (0.1605). Direct effect of corm breadth on yield per plant was positive (0.2881) attitude in nature. Indirect effects were noticed through plant height (0.1353), petiole length (0.1639) and corm length (0.4630). Positive indirect effects also found through plant height (0.1826), petiole length (0.3893), leaf area index (0.2156), spathe length $(0.2377)$, spathe breadth $(0.214)$ and corm breadth (0.3169).

Table II. Direct (Diagonal bold ) and indirect effects for yield and yield contributing characters of giant taro, (Alocasia macrorhiza L.) in genotypic (G) and phenotypic (P) level

\begin{tabular}{|c|c|c|c|c|c|c|c|c|c|c|c|}
\hline CHARACTERS & PLH & PEL & PEB & LAI & IFL & IFN & SPL & SPB & CRL & CRB & YPP \\
\hline PLH & 0.1706 & 0.0019 & -0.0407 & 0.0304 & 0.0790 & 0.0050 & 0.1291 & 0.0475 & 0.4855 & 0.2285 & 0.544 \\
\hline $\begin{array}{l}\mathbf{G} \\
\mathbf{P}\end{array}$ & 0.4800 & 0.7887 & -0.0409 & -0.1425 & -0.0119 & 0.0208 & 0.0451 & 0.0010 & 0.0183 & 0.1609 & 0.421 \\
\hline $\begin{array}{l}\text { PEL } \\
\text { G }\end{array}$ & $\begin{array}{l}0.0006 \\
0.4243\end{array}$ & $\begin{array}{l}0.5340 \\
0.8922\end{array}$ & $\begin{array}{l}-0.0697 \\
-0.0286\end{array}$ & $\begin{array}{l}0.0029 \\
-0.0683\end{array}$ & $\begin{array}{l}0.0742 \\
-0.0075\end{array}$ & $\begin{array}{l}0.0042 \\
0.0119\end{array}$ & $\begin{array}{l}0.0585 \\
0.0392\end{array}$ & $\begin{array}{l}-0.0196 \\
0.0015\end{array}$ & $\begin{array}{l}0.2086 \\
0.0063\end{array}$ & $\begin{array}{l}0.0884 \\
0.0642\end{array}$ & $\begin{array}{l}0.645 \\
0.788\end{array}$ \\
\hline $\mathbf{P}$ & & & & & & & & & & & \\
\hline PEB & -0.0285 & -0.1527 & 02437 & 0.0107 & 0.0522 & -0.0028 & 0.0321 & 0.0112 & 0.0831 & 0.0268 & 0.360 \\
\hline $\begin{array}{l}\mathbf{G} \\
\mathbf{P}\end{array}$ & 0.3331 & 0.4336 & $-\mathbf{0 . 0 5 8 9}$ & -0.0636 & -0.0080 & 0.0078 & 0.0701 & 0.0017 & 0.0036 & 0.0299 & 0.050 \\
\hline LAI & 0.0160 & 0.0048 & 0.0080 & 0.3232 & 0.0097 & 0.0007 & 0.0680 & 0.0024 & 0.1771 & 0.0879 & 0.293 \\
\hline $\begin{array}{l}\mathbf{G} \\
\mathbf{P}\end{array}$ & 0.4819 & 0.4292 & -0.0264 & -0.1420 & -0.0092 & 0.0088 & 0.1034 & 0.0011 & 0.0077 & 0.0314 & 0.215 \\
\hline $\begin{array}{l}\text { IFL } \\
\text { G }\end{array}$ & $\begin{array}{l}0.1655 \\
-0.1968\end{array}$ & $\begin{array}{l}0.4870 \\
-0.2284\end{array}$ & $\begin{array}{l}0.1562 \\
0.0162\end{array}$ & $\begin{array}{l}0.0385 \\
0.0447\end{array}$ & $\begin{array}{l}\mathbf{0 . 0 8 1 4} \\
\mathbf{0 . 0 2 9 1}\end{array}$ & $\begin{array}{l}-0.0166 \\
-0.0227\end{array}$ & $\begin{array}{l}-0.2567 \\
-0.2163\end{array}$ & $\begin{array}{l}-0.2333 \\
0.0191\end{array}$ & $\begin{array}{l}0.4830 \\
0.0115\end{array}$ & $\begin{array}{l}0.2406 \\
0.0648\end{array}$ & $\begin{array}{l}0.545 \\
0.150\end{array}$ \\
\hline $\mathbf{P}$ & & & & & & & & & & & \\
\hline IFN & -0.0367 & -0.0961 & 0.0300 & -0.0100 & -0.0166 & -0.0231 & 0.1291 & 0.0139 & 0.0748 & 0.0164 & 0.121 \\
\hline $\begin{array}{l}\mathbf{G} \\
\mathbf{P}\end{array}$ & 0.1507 & 0.1606 & -0.0070 & -0.0187 & -0.0227 & 0.0663 & 0.1085 & 0.0015 & 0.0019 & 0.0398 & 0.052 \\
\hline SPL & -0.0927 & -0.1314 & -0.0329 & -0.0924 & 0.0879 & 0.0125 & -0.2377 & -0.0066 & -0.2244 & -0.1196 & -0.338 \\
\hline G & 0.0552 & 0.0892 & -0.0105 & & -0.0161 & 0.0184 & 0.3918 & 0.0007 & 0.0067 & & -0.202 \\
\hline $\mathbf{P}$ & & & & -0.0375 & & & & & & -0.0381 & \\
\hline SPB & -0.0369 & 0.0475 & -0.0124 & -0.0036 & 0.0863 & 0.0015 & -0.0071 & -0.2201 & -0.0956 & -0.0484 & -0.110 \\
\hline $\begin{array}{l}\mathbf{G} \\
\mathbf{P}\end{array}$ & 0.0235 & 0.0633 & -0.0047 & -0.0075 & 0.0268 & 0.0049 & 0.0137 & 0.0208 & 0.0047 & -0.0293 & -0.096 \\
\hline CRL & 0.0997 & 0.1340 & 0.0244 & 0.0689 & 0.0473 & -0.0021 & 0.0642 & 0.0253 & 0.8313 & 0.1605 & 0.510 \\
\hline $\mathbf{G}$ & 0.2073 & 0.1329 & & -0.0257 & 0.0079 & 0.0029 & 0.0619 & 0.0023 & 0.0423 & 0.1412 & 0.468 \\
\hline $\mathbf{P}$ & & & -0.0050 & & & & & & & & \\
\hline CRB & 0.1353 & 0.1639 & 0.0227 & 0.0986 & 0.0680 & -0.0013 & 0.0986 & 0.0370 & 0.4630 & 0.2881 & 0.600 \\
\hline G & 0.2659 & 0.1972 & & -0.0153 & 0.0065 & 0.0091 & -0.0 .513 & -0.0021 & 0.0206 & 0.2905 & 0.522 \\
\hline $\mathbf{P}$ & & & -0.0061 & & & & & & & & \\
\hline
\end{tabular}

Residual effect $=0.4762 \quad(G)$, Residual effect $\quad=0.4235(\mathrm{P}) \quad *$ Significant at 0.05 level $* *$ significant at 0.01 level

Plant height (PLH), Petiole length (PEL), Petiole breadth (PEB), Leaf area Index (LAI), Inflorescence length (IFL), Inflorescence number, Spathe length (SPL), Spathe breadth (SPB), Corm length (CRL), Corm breadth (CRB), Corm weight $(C R W)$, Yield per plant $(Y P P)$. 
At phenotypic level direct effect of plant height on yield per plant was positive $(0.4800)$. Indirect positive effects also found through petiole length $(0.7887)$ and corm breadth (0.1609). The positive direct effect together with positive and indirect effect through plant height $(0.4243)$ and together with other characters low values mobilized the correlation highly strong and positive $\left(r_{p}=0.788\right)$. Indirect effects also found positive through plant height $(0.3331)$ and petiole length (0.4336). Leaf area index showed positive indirect effects were observed through plant height (0.4819), petiole length (0.4292), and spathe length (0.1034). The direct effect of spathe length on yield per plant was positive (0.3918). The direct effect of corm length on yield per plant was positive (0.0423). Positive indirect effects were observed via plant height $(0.2073)$, petiole length $(0.1329)$ and corm breadth (0.1412). The direct effect of corm breadth on yield per plant was positive (0.2905). Indirect positive effects were observed via plant height (0.2659), and petiole length (0.1972).

Giant taros are underutilized and neglected crop and very few research works were reported on its areas of correlation and path analysis. Chand and Co-workers (Chand et al., 1987) studied in taro that at the magnitude of genotypic correlation coefficients was in general higher than phenotypic ones. Yield was positively and significantly correlated with L/B ratio of leaves and number of suckers per plant at both genotypic and phenotypic levels. High positive correlation between plant height and size of corms, L/B ratio and size of corm was observed at genotypic level. (Mahon Kumar et al.,1990) showed that the characters such as mean weight of cormels/ plant, number of cormels / plant and LAI were positively and significantly correlated with yield. Goenaga and Co-workers (Goenaga et al., 1994) observed yield per plant was significantly and positively correlated with most of characters at both phenotypic and genotypic levels in tanier plants. Pandey and Co-workers (Pandey et al., 1996) studied 31 genotypes of taro with 8 yield contributed characters and observed that yield per plant was significantly and positively correlated with most of character at both phenotypic and genotypic levels. Dwivedi and Sen (Dwivedi and Sen, 1999) studied thirty genotypes of taro for correlation and observed that cormel yield had positive and significant association with the length and girth of main sucker, number of cormels per plant and corm weight but it was negatively correlated with corm /cormel ratio. Velayudhan and Co-workers (Velayudhan, et al., 2000) found that the characters cormel number, cormel thickness, plant height, leaf length and leaf width had higher positive correlation with cormel yield where as leaf number was negatively correlated with yield. Tsegaye and Co-workers (Tsegaye et al., 2006) studied thirty sweet potato genotypes selected at random from the germplasm collection of diverse origin and they analyzed phenotypic and genotypic correlation coefficient revealed that storage root yield had positive and significant correlation with individual storage root weight, harvest index and storage root girth. Number of storage root per plant was negatively and significantly correlated with individual storage root weight and storage root girth indicating the presence of compensatory relationship between number of storage roots per plant and the latter two traits. Cheema and Co-workers (Cheema et al. (2007) studied in arvi total yield per plant was positively and significantly correlated with number of corms and cormels per plant and corm length. In most of the cases the findings of these research workers directly corroborates with this research results.

In phenotypic level plant height showed significant and positive correlation with petiole length, petiole breadth, LAI and corm breath. It means that through photosynthetic activities by these characters yield per plant can be accelerated. With the increase of corm breadth and corm length increases yield per plant. Among the characters path analysis showed that plant height, petiole length, petiole breath, LAI, inflorescence length, corm length, corm breadth have direct positive effect on yield per plant. The residual effect 0.4762 represent only about $53 \%$ of the variability observed for yield per plant was represented by these traits. In the phenotypic level positive direct effect was found on yield per plant by plant height, petiole length, inflorescence length, inflorescence number, spathe length and spathe breadth, corm length, corm breadth. The residual effect 0.4235 means that characters included in the present study explained about $58 \%$ variability in yield per plant.

\section{Acknowledgement}

Expression of gratefulness to Institute of Biological Sciences, University of Rajshahi, Rahshahi -6205, Ministry of Science and Technology \& communication, Government of Bangladesh and University Grant Commission (UGC), Agargaon, Dhaka-1207 for their partial financial support as fellowship to first author.

\section{References}

Ahmed, S 2003. Oushadhi Udvid, Dibyaprakash, Bangladesh, p-103.

Al-Jibouri HA, Miller, RA and Robinson, H F (1958). Genotypic and environmental variances and covariances in an upland cotton across of interspecific origin. Agron. J. 50: 633-37.

Anonymous, IBPGRI (1999). Descriptors for taro (Colocasia esculenta ). IPGRI, Rome, Italy. 
Chand B, Jaiawal RC and Gautam NC (1987). Genetic variability and correlation studies in Colocasia. (C.esculenta.L.). Haryana j. of Hort. Sci. 16(1/2): 134-139.

Cheema DS, Singh H, Datt, A S and Gang N 2007.Studies on genetic variability and correlation for yield and quality traits in Arvi(Colocasia esculenta Schott).

Cochran WG and Cox G M 1960. Experimental design. $2^{\text {nd }}$ edition. John Willy and Sons, Inc. NewYork.

Coursey DG 1967. The edible aroids. World Crops. 20(4): 25-30.

Dewey D I and Lu KH 1959. A Correlation and Path coefficient analysisof components of created wheat grass seed production.Agron.J. 51: 515-18.

Dwivedi A K and Sen H (1999). Correlation and path coefficient studies in taro (colocasia esculenta var.antiquorum).J. root crops. 25(1): 51-54.

Fisher, RA, Immer, RR and Tedin, O 1932. The genetic interpretation of statisticson the third degree in the inheritance of Quantitative inheritance. Genetics, 17: 107-124.

Ghani A 1988, Medicinal plants of Bangladesh with chemical constituents and uses. Second edition. Asiatic Society of Bangladesh. Dhaka, p-85.

Goenaga R (1994). Growth, nutrient uptake and yield of tanier (Xanthosoma spp.) grown under semiarid conditions. J. Agric. University P R. 78(3-4): 87-98. 18 ref.

Leon J 1977. Origin, evolution and early dispersal of root crops. Proceedings of the $4^{\text {th }}$ symposium of the international society of tropical root crops (Colombia, 1976), IDRC -080e (Cock, J, Macintyre, R and Graham, M.,eds, pp 20-36. Ottawa,Canada: International Development Research Centre, p-277.

Mather, K (1949). Biometrical Genetics, Dover Publication. Inc. New York.

Miller 66 D A, Willium JC, Robinson, HF, Comstock RE (1958). Estimates of genotypic and environmental variances and covariances in upland cotton and their implications in selection. Agron. J. 50:126-131.

Montgomery E G (1911). Correlation studies in corm. Nebr. Agr . Exp. Sta. Ann .Rep. 24: 108-159.
Mohon Kumar C R, Sarawathy P and Sadanandan N (1990). Correlation and path coefficient analysis on yield and yield component in Taro. J Root Crops 16(2): 140-141.

Pandey G, Dhobal V K and Sapra RL (1996). Genetic variability, correlation and path analysis in Taro. (Colocasia esculenta). J. Hill .Res. (India) 9(2): 299-302.

Plucknett DC 1970. Status and future of the major edible aroids: Colocasia, Xanthosoma, Alocasia, Cyrtosperma and Amorphophallus. Second International Symposium.Trop. Root Crops (Honolulu.).

Purseglove, JW 1972. Araceae. TropicalCrops: Monocotyledons 1, London. Longman group Ltd. pp58-74.

Rashid MM and Daunicht HJ (1979). Chemical composition of nine edible aroid cultivarsof Bangladesh. Scientia Horticulturae. 10: 127-134.

Singh (1980). Path analysis in Lin seed under Sodic soil conditions In: J Genet .P. Breed. 40: 385-387.

Singh R K and Chaudhary B D (1977). Biometrical methods in quantitative genetic analysis .Kalnani publishers, New Delhi, India.

Tsegage Engida, Nigussie E V, Dechassa and Devakara Sastry (2006). Correlation and path analysis in sweet potato and their implications for clonal selection. Journal of Agronomy 5(3): 391-395.

Velayudhan, K C, Leji R S and Rajlakshmy C (2000). Correlation and path analysis in Taro (Colocasia esculenta L.Schott ) morphotypes. J. Root crops 26(2): 36-39.

Wright, S (1921).Correlation and causation. J. Agric Res. 20: 557-585.

Wright, S (1923).The theory of Path coefficient a reply to Niles critism. Genetics. 8: 239-255.

Received: 15 May 2012; Revised: 28 January 2015; Accepted: 24 March 2015. 